ROCZNIKI TEOLOGICZNE

Tom LXVII, zeszyt 3 - 2020

DOI: https://doi.org/10.18290/rt.20673-6

\author{
ANDRZEJ DERDZIUK OFMCap
}

\title{
REALIZACJA POWOŁANIA ZAKONNEGO MAURYCEGO LUDWIKA KUBRAKA OFMCap (1937-1987)
}

\author{
REALIZATION OF THE RELIGIOUS VOCATION \\ OF MAURYCY LUDWIK KUBRAK OFMCap (1937-1987)
}

\begin{abstract}
The figure of Capuchin Maurycy Ludwik Kubrak (1937-1987) was remembered as a charismatic priest who influenced the faithful with his humbleness, simplicity and the spirit of piety and poverty. While working in Biała Podlaska and Lublin as a religion teacher, he was called a catechist with a magnet. In his service as a hospital chaplain in Lublin and in pastoral work for the nuns in Nowe Miasto, he was faithful to his duties and sacrificial availability which spared no effort. As a parish priest in Rywałd Królewski, he spread the Marian cult and developed pastoral work in the sanctuary. His patience and love for the cross was revealed during his terminal illness, which he experienced with exceptional submission to God's will. He died in the opinion of holiness.
\end{abstract}

Key words: Capuchins; Maurycy Kubrak; holiness; pastoral care.

Przesłanie teologii moralnej staje się bardziej czytelne i przekonywujące, gdy zostaje zilustrowane przykładami życia ukazującymi realizm i aktualność ideałów wskazanych w Ewangelii. Ludzie, którzy aspirują do doskonałości w miłości i na serio traktują powołanie do świętości, są potwierdzeniem, że dążenie teologów moralistów do ukazania czytelnych kryteriów dobra i zła jest nie tylko zasadne, ale też może być użyteczne i przynosi błogosławione

Prof. dr hab. ANDRZEJ DeRDZIUK OFMCap - Katedra Teologii Moralnej Społecznej, Instytut Nauk Teologicznych, Katolicki Uniwersytet Lubelski Jana Pawła II; adres do korespondencji: Al. Kraśnicka 76, 20-718 Lublin; e-mail: aderdziu@kul.pl; ORCID: https// orcid.org/0000-0003-4678-726X. 
owoce. Takim przykładem usilnego dążenia do świętości był student studium pastoralnego KUL w latach 1972-1976, ojciec Ludwik Maurycy Kubrak przynależący do wspólnoty Zakonu Braci Mniejszych Kapucynów Prowincji Warszawskiej.

Jego życie i działalność stanowiły przedmiot kilku opracowań naukowych, ale nie ukazano całościowej drogi jego posługi duszpasterskiej i działalności naukowej ${ }^{1}$. Podziwiany przez swoich współbraci i wiernych placówek duszpasterskich, w których posługiwał, jest przez wielu uważany na wzór człowieka w pełni oddanego Bogu i ludziom. Niniejszy artykuł ukazuje jego biografię oraz prezentuje istotne rysy jego duchowości.

\section{OKRES DZIECIŃSTWA I FORMACJI ZAKONNEJ}

Ludwik Kubrak przyszedł na świat 20 lipca 1937 roku w Czarnocinie w parafii Piątnica koło Łomży ${ }^{2}$. Jego rodzice Ignacy i Anna z domu Kijek prowadzili gospodarstwo rolne o powierzchni 6 hektarów. Odznaczali się głęboką pobożnością i przekazali swoim dzieciom wiarę w Boga oraz przywiązanie do polskości. W rodzinie była czwórka dzieci: dwie dziewczynki i dwóch chłopców. Od czasu pierwszej Komunii Świętej Ludwik odznaczał się głęboką pobożnością eucharystyczną i z ogromną miłością przyjmował Chrystusa w postaciach sakramentalnych. Okazywał też ponadprzeciętne oznaki pobożności, umartwiając swoje ciało i podejmując dodatkowe modlitwy. Pierwsze trzy klasy szkoły podstawowej Ludwik zaliczył w Czarnocinie, a potem zaczął uczęszczać do szkoły w Piątnicy. Rodzinna miejscowość była terenem posługi duszpasterskiej kapucynów z klasztoru w Łomży, którzy przybywali tu na kwestę oraz uprawiali łąkę położoną nieopodal domu Kubraków. Mieszkańcy wsi często udawali się do pobliskiego klasztoru, gdzie korzystali ze spowiedzi u kapucynów i uczestniczyli w nabożeństwach, zwłaszcza w odpuście Porcjunkuli.

Kierując się pragnieniem poświęcenia się Bogu, Ludwik w 1951 roku podjął naukę w niższym seminarium Księży Salezjanów w Różanymstoku.

${ }^{1}$ Por. A.P. DYDYCZ, Życie poświęcone Bogu, w: TENŻE, Niosac ziarno na zasiew, RzymLublin 1992, s. 219-234; J.M. CYGAN, Maurycy Kubrak, kapucyn, we wspomnieniach mieszkańców Białej Podlaskiej, „Podlaski Kwartalnik Kulturalny” 1995, nr 1, s. 29-41.

${ }^{2}$ Por. A. Derdziuk, Świadkowie mitości Boga i człowieka, w: Fructus Spiritus est Caritas. Księga jubileuszowa ofiarowana Księdzu Profesorowi Franciszkowi Draczkowskiemu, red. M. Wysocki, Wydawnictwo KUL, Lublin 2011, s. 587-590. 
Systemowi prewencyjnemu Księdza Bosko zawdzięczał zdolność do przekraczania swej wrodzonej nieśmiałości oraz pokonywania dokuczającego mu poczucia mniejszej wartości. Kiedy seminarium zostało zamknięte przez władze komunistyczne w 1954 roku, zdecydował się na wstąpienie do Warszawskiej Prowincji Braci Mniejszych Kapucynów33. W zachowanym podaniu do Prowincjała napisał: ,już od młodych lat pragnąłem swe życie poświęcić Bogu [...] doszedłem do przekonania, że tylko w tym Zakonie uświęcę własną duszę i będę wspomagał bliźnich, o ile to będzie w mojej mocy"4.

Do klasztoru nowicjackiego przybył na początku sierpnia. Podczas obłóczyn 14 VIII 1954 roku przyjął imię Maurycy i rozpoczął nowicjat w Nowym Mieście nad Pilicą. Przez pierwsze miesiące magistrem nowicjatu był o. Benedykt Drozdrowski, a potem o. Ambroży Jastrzębski. Socjuszem magistrów był przez cały rok o. Michał Skorupiński. Wszyscy ci trzej zakonnicy mieli za sobą kilkuletni okres pobytu w niemieckich obozach koncentracyjnych, co pozostawiło ślad $w$ ich nastawieniu do życia. Niekiedy też metody wychowawcze stosowane w nowicjacie, wyrażające się w surowej dyscyplinie i braku indywidualnego podejścia do braci, za bardzo nawiązywały do wcześniejszych doświadczeń wychowawców. Brat Maurycy złożył swoje pierwsze śluby zakonne na okres trzech lat dnia 15 sierpnia 1955 roku$^{5}$.

Ponieważ w tym czasie władze komunistyczne pozamykały niższe seminaria duchowne oraz zlikwidowały w Lublinie katolicką szkołę zwaną Biskupiakiem, kapucyni zorganizowali własną tajną szkołę średnią w Nowym Mieście, gdzie młodzi zakonnicy kończyli X i XI klasę. Wykładowcami byli kapłani kapucyńscy, siostry ze zgromadzeń honorackich oraz kilku nauczycieli świeckich. Jeden z tych nauczycieli, późniejszy kapucyn, o. Edward Szelachowski zapamiętał brata Maurycego jako młodzieńca rozmodlonego, odznaczającego się wewnętrznym skupieniem, uwaga i pilnością ${ }^{6}$.

Po ukończeniu XI klasy w Nowym Mieście brat Maurycy w 1956 roku został skierowany do Wyższego Seminarium Duchownego Kapucynów w Łomży, gdzie przygotowywał się do święceń kapłańskich. Seminarium miało charakter tradycyjnego studium domesticum, gdzie wykładowcami byli bracia kapucyni. Brat Maurycy wyróżniał się jako sprawny sportowiec, który świetnie grał

\footnotetext{
${ }^{3}$ Por. A.P. DyDYCZ, Życie poświęcone Bogu, s. 221.

${ }^{4}$ Por. G. BARToszewski, Świętość niekanonizowana Warszawskiej Prowincji Braci Mniejszych Kapucynów, w: W stużbie pokoju i dobra. Jubileusz pięćdziesięciolecia odrodzenia Warszawskiej Prowincji Kapucynów. Księa pamiatkowa, red. R. Prejs, Warszawa 2002, s. 397.

${ }^{5}$ Por. A.P. DyDYCZ, Życie poświęcone Bogu, s. 222.

${ }^{6}$ Por. J.M. CyGan, Maurycy Kubrak, kapucyn, s. 39.
} 
w piłkę siatkową, a także służył wspólnocie kleryckiej jako organista, akompaniując na organach i fisharmonii podczas nabożeństw. W roku $1961 \mathrm{w}$ Łomży złożył zakonne śluby wieczyste. Dnia 29 VI 1963 roku przyjął prezbiterat z rąk biskupa łomżyńskiego Czesława Falkowskiego. Przełożeni chcieli go wysłać na studia specjalistyczne do Rzymu, ale na przeszkodzie stanęła odmowa wydania paszportu przez władze komunistyczne. Zwyczajem kapucyńskim podjął zatem roczne przygotowanie do sprawowania funkcji duszpasterskich nazywane tirocinium, które było kierowane przez o. Gabriela Bartoszewskiego i miało miejsce w klasztorze w Lublinie przy Krakowskim Przedmieściu ${ }^{7}$.

\section{POSŁUGA DUSZPASTERSKA W BIAŁEJ PODLASKIEJ I LUBLINIE}

Pierwszym miejscem pracy duszpasterskiej, do której skierowali go przełożeni po ukończeniu przygotowania duszpasterskiego w 1964 roku, była rozrastająca się parafia w Lublinie na Poczekajce, gdzie z gorliwością uczył katechezy i spowiadał. W kronice klasztornej zanotowano, że o. Maurycy został przysłany wraz z innymi kapłanami. Byli to o. Beda Bujnowski oraz o. Bernardyn Mazur. Zamienili oni dwóch wikarych, z których jeden udał się do pracy wśród Polaków w USA, a drugi awansował na gwardiana w klasztorze przy Krakowskiem Przedmieściu w Lublinie ${ }^{8}$.

Czas pracy na Poczekajce był związany z okresem Wielkiej Nowenny przed tysiącleciem chrześcijaństwa w Polsce i w parafii było prowadzonych wiele inicjatyw w tym zakresie. Po roku owocnej posługi, prowincjał zdecydował o przeniesieniu o. Maurycego do Białej Podlaskiej. Decyzja ta nie spodobała się ówczesnemu proboszczowi, który tak opisał to w kronice parafialnej: „Dnia 26 sierpnia b.r. o. Prowincjał Piotr Gacki a Zanklewo zabrał z naszej parafii o. Maurycego Kubraka, który tak ładnie zaczął tu pracować. Powód? Rzekomo gdzie indziej jest potrzebny. W rzeczywistości obecny Prowincjał nie ma zrozumienia dla pracy duszpasterskiej na parafii" $"$.

Motywacja prowincjała była jednak zgoła odmienna. Bardzo ceniąc zdolności duszpasterskie o. Maurycego, przeznaczył go do pracy w Białej Podlaskiej. Sytuacja w tym mieście była nietypowa, bowiem Biskup Siedlecki

\footnotetext{
${ }^{7}$ Por. L. Kubrak, Podanie o przyjęcie na studia na KUL, 28 IX 1972, Archiwum KUL, sygnatura T 23340.

${ }^{8}$ Por. Kronika parafii Niepokalanego Serca Maryi, Lublin Konstantynów, zapis pod datą 1 IX 1964, Archiwum klasztoru w Lublinie II.

${ }^{9}$ Por. tamże, zapis pod datą 26 VIII 1965.
} 
Ignacy Świrski chciał sprowadzić do Białej kapucynów i przekazać im klasztor poreformacki. Było to związane z sympatią biskupa do Zakonu Kapucynów, ale też z pragnieniem uczczenia postaci Honorata Koźmińskiego, który w tym mieście się urodził i wzrastał. Jednak władze państwowe nie pozwalały na objęcie przez zakonników nowych placówek. Wobec tego pod pozorem pomocy duszpasterskiej, biskup sprowadził dwóch kapłanów kapucyńskich, którzy pomagając kapłanom diecezjalnym, z czasem mieli całkowicie przejąć klasztor. Dom zakonny reformatów został bowiem skasowany po Powstaniu Styczniowym i kościół był obsługiwany przez księży diecezji siedleckiej Edmunda Barbasiewicza i Zbigniewa Latosiego ${ }^{10}$.

Maurycy Kubrak przybył do Białej Podlaskiej 25 sierpnia 1965 roku i zamieszkał w części klasztoru niezajętej przez szkołę. Podjął obowiązki katechety w szkołach zawodowych: Zasadniczej Szkole Odzieżowej, Zasadniczej Szkole Handlowej, Technikum Ekonomicznym, Technikum Gastronomicznym oraz I Liceum Ogólnokształcącym imienia Józefa Ignacego Kraszewskiego. Każdego roku obejmował nauczaniem około 900 uczniów. Dał się poznać jako charyzmatyczny nauczyciel religii, który nie tylko przekazywał treści wiary, ale też dawał jej czytelne świadectwo, co sprawiało, że nazywano go „katechetą z magnesem"11. Przyciągał bowiem na lekcję młodzież, która wcześniej nie uczęszczała na katechezę i wywierał na nich delikatny, ale bardzo skuteczny wpływ przez swoje umiłowanie modlitwy, ubóstwo, skromność, uprzejmość i delikatność. Emanujący od niego pokój udzielał się uczniom, którzy nie przeszkadzali mu w prowadzeniu lekcji i aktywnie włączali się w życie religijne. Zebrane świadectwa ukazuja go jako człowieka cieszącego się opinią świętości i szanowanego przez wszystkich.

Decyzja prowincjała, który wysłał o. Maurycego celem przeszczepienia zakonu do Białej Podlaskiej, była bardzo owocna i sprawiła, że kapucyni w 1968 roku przejęli kościół, a z czasem odzyskali cały klasztor ${ }^{12}$. Razem z Kubrakiem pracowali w tym okresie o. Pacyfik Antoni Dydycz oraz Maksymilian Macioszek. Pierwszy z nich był cenionym kaznodzieją i organizatorem wydarzeń duszpasterskich. Dwaj pozostali nazywani byli świętymi katechetami ${ }^{13}$.

\footnotetext{
${ }^{10}$ Por. J.M. CyGAN, Maurycy Kubrak, kapucyn, s. 29-30.

11 Por. tamże, s. 32.

12 Por. G. BARToszewsKi, Świętość niekanonizowana, s. 397.

13 Por. J.M. Cygan, Maurycy Kubrak, kapucyn, s. 37.
} 
Dnia 7 lipca 1972 roku ojciec Maurycy przybył do klasztoru kapucyńskiego w Lublinie, gdzie miał zastąpić ojca Franciszka Rożkowskiego w posłudze w lubelskich szpitalach ${ }^{14}$. Od 10 lipca 1972 roku został kapelanem szpitala kolejowego w Lublinie przy ulicy 1 Maja oraz szpitala neurologicznego w Abramowicach, gdzie pracował społecznie ${ }^{15}$. Praca polegała na tym, że w sobotę chodził po oddziałach szpitalnych i spowiadał tych, którzy chcieli przyjąć sakrament pokuty. Zaś w niedzielę udzielał Komunii Świętej chorym, którzy przychodzili do pokoju dyżurnego przy portierni szpitala. Tym, zaś którzy nie mogli chodzić, ojciec Maurycy zanosił Komunię Świętą do sal szpitalnych. Intencje przyjmowane od pacjentów odprawiał w klasztorze przy Krakowskim Przedmieściu, gdzie sprawował Mszę świętą zbiorową.

Był to niezwykły czas, gdy zasadniczo posługa kapelanów była zabroniona i kapłani mogli wchodzić do szpitala jedynie dzięki uprzejmości personelu medycznego. Osobą, która pomagała kapucynom w docieraniu do pacjentów szpitala kolejowego, była pani Halina Łodzia-Śmigielska, która tam pracowała. W opisie posługi w szpitalach ojciec Maurycy nie zawarł informacji, że napotykał sprzeciw ze strony lekarzy i pielęgniarek. Szczególnym owocem jego posługi w szpitalu było nawrócenie osoby należącej do niekatolickiej wspólnoty Badaczy Pisma Świętego. Kobieta była córką przewodniczącego tej grupy wyznaniowej i żoną zaangażowanego członka wspólnoty. Dzięki odpowiedniej lekturze religijnej oraz rozmowom i modlitwie, osoba ta złożyła wyznanie wiary katolickiej i przyjęła sakramenty Kościoła. Po nawróceniu przez około dziesięć lat korespondowała z ojcem Maurycym na tematy duchowości katolickiej.

Będąc jednocześnie kapelanem i studentem KUL, ojciec Maurycy podejmował także inne obowiązki duszpasterskie. W kronice klasztornej jest adnotacja, że od dnia 3 listopada 1972 roku prowadził nabożeństwo czterdziestogodzinne w parafii Perlejewo w diecezji drohiczyńskiej ${ }^{16}$. W Wielkim Poście roku 1983 wygłosił rekolekcje wielkopostne w parafiach Wandów oraz Bończa ${ }^{17}$. W ramach posługi w innych klasztorach kapucyńskich w dniu 29 czerwca 1973 roku wygłosił kazania odpustowe w Serpelicach ${ }^{18}$.

\footnotetext{
${ }^{14}$ Por. Dzieje klasztoru lubelskiego OO. Kapucynów w drugim 1000-leciu chrześcijaństwa w Polsce, Kronika klasztorna, Archiwum klasztoru w Lublinie I, zapis pod data 7 VII 1972.

15 Por. A. SZYMAŃsKi, Cicha działalność kapelańska o. Maurycego Kubraka, w: TENŻE, Kapucyni kapelani szpitalni i więzienni po drugiej wojnie światowej w Lublinie, mps, Biblioteka WSD Kapucynów w Lublinie, Lublin 1983, s. 15-16.

${ }^{16}$ Por. Dzieje klasztoru lubelskiego, zapis pod datą 7 VII 1972.

${ }^{17}$ Por. Dzieje klasztoru lubelskiego, zapisy pod datą 18 III 1973 i 22 III 1973.

18 Por. Dzieje klasztoru lubelskiego, zapis pod datą 19 VI 1973.
} 
Doświadczając wielu trudności w podejmowanych pracach, o. Maurycy poddał się badaniom i wówczas zdiagnozowano u niego silną nerwicę ${ }^{19}$. Na podstawie takiej diagnozy, po rocznej pracy w szpitalu oraz pełnieniu posługi spowiednika w klasztornym kościele kapucynów w Lublinie przy Krakowskim Przedmieściu 42, ojciec Maurycy poprosił prowincjała o zwolnienie z tych obowiązków i od dnia 14 września 1973 roku przestał przynależeć do familii klasztoru lubelskiego ${ }^{20}$.

W czasie pobytu w Lublinie, od października 1972 roku Kubrak podjął studia magisterskie na KUL w ramach studium pastoralnego na Wydziale Teologii. Ponieważ nie posiadał matury, musiał uzyskać specjalne pozwolenie z ministerstwa nauki, szkolnictwa wyższego i techniki, by być zwolnionym z obowiązku składania świadectwa dojrzałości ${ }^{21}$. W trakcie studiów uczęszczał między innymi na wykłady ks. Wojciecha Danielskiego i ks. Adama Ludwika Szafrańskiego. W czerwcu 1973 roku złożył podanie o zatwierdzenie pracy magisterskiej na temat: „Mariologia ojca Honorata Koźmińskiego na podstawie dzieła Czem jest Maryja", przygotowywanej pod kierunkiem ks. prof. Józefa Kudasiewicza ${ }^{22}$. Magisterium uzyskał na podstawie pracy i egzaminu magisterskiego z dnia 26 maja 1975 roku przed komisją pod kierunkiem o. prof. Hugolina Langkammera $\mathrm{OFM}^{23}$.

Po uzyskaniu pozwolenia władz zakonnych, o. Maurycy ${ }^{24}$ w sierpniu 1975 roku złożył podanie o przyjęcie na studia licencjacko-doktoranckie w Instytucie Teologii Pastoralnej na kierunek homiletyka ${ }^{25}$. W trakcie pierwszego roku studiów zdał egzamin z języka niemieckiego na ocenę bardzo dobrą i został zwolniony z uczęszczania na lektorat $\mathrm{z}$ tego języka. Na pierwszym roku studiów do licencjatu kościelnego zaliczał też egzaminy z przedmiotów, które są w programie roku drugiego ${ }^{26}$. Z kolei na roku II zaczął już zaliczać przedmioty z roku trzeciego. Otrzymywał oceny bardzo dobre

${ }^{19}$ Por. A.P. DYDYCZ, Życie poświęcone Bogu, s. 224.

${ }^{20}$ Por. A. SZYMańsKi, Cicha dziatalność kapelańska, s. 16.

${ }^{21}$ Por. L. KASPRZYK, Pozwolenie ministerstwa nauki, szkolnictwa i techniki, z dnia 19 lutego 1973 roku, Archiwum KUL, sygnatura T 23340.

22 Por. L. Kubrak, Podanie do Rady Wydziatu Teologicznego KUL, Archiwum KUL, sygnatura T 23340 .

${ }^{23}$ Por. Protokót komisji egzaminu magisterskiego, Archiwum KUL, sygnatura T 23340.

${ }^{24}$ Por. G. BArtoszewski, Zaświadczenie, Archiwum KUL, sygnatura T 23340.

${ }^{25}$ Por. L. Kubrak, Podanie do Księdza Dziekana Wydziału Teologicznego KUL, Archiwum KUL, sygnatura T 23340.

${ }^{26}$ Po. L. Kubrak, Pismo do Dziekana z dnia 13 stycznia 1976 roku, Archiwum KUL, sygnatura $\mathrm{T} 23340$. 
i dobre. Licencjat kościelny otrzymał na podstawie egzaminu zdanego w dniu 15 czerwca 1976 roku $^{27}$. Po kilku latach poprosił o urlop dziekański, ale nie kontynuował rozpoczętej pracy nad doktoratem ${ }^{28}$.

\section{POBYT W INNYCH KLASZTORACH PROWINCJI}

Od 1973 roku o. Maurycy został przeniesiony do Nowego Miasta nad Pilicą, gdzie zajmował się duszpasterstwem sióstr zakonnych, odprawiając Msze święte w kaplicach sióstr ze zgromadzeń honorackich oraz głosząc konferencje w ramach dni skupienia i spowiadając siostry w domach zakonnych. W tym czasie kontynuował studia w Lublinie oraz podejmował się głoszenia kazań podczas odpustów i rekolekcji w różnych parafiach. Jego skrupulatność w przygotowywaniu zajęć sprawiała, że przed każdym wystąpieniem długo się modlił i opracowywał na piśmie wygłaszane konferencje i kazania. Mimo tego miał poczucie niewłaściwego spełniana swych obowiązków, co wyrażało się w przepraszaniu ludzi, że za mało ukazuje im Chrystusa. Taka sytuacja wydarzyła się już podczas rekolekcji wielkopostnych w Komarnie, gdy na zakończenie kazania uklęknął przy ambonie i pokornie przepraszał ludzi, iż tak marnie wypełniał swój obowiązek. Obiecał też, że będzie się za nich dalej modlił, by wynagrodzić im brak należytego spełnienia posługi słowa ${ }^{29}$.

W trakcie wakacji 1976 roku ojciec Maurycy otrzymał obediencję od prowincjała Pacyfika Antoniego Dydycza, że dnia 19 sierpnia tego roku winien stawić się w klasztorze kapucynów w Lublinie na Poczekajce, gdzie miał objąc posługę duszpasterza $\mathrm{w}$ parafii ${ }^{30}$. Po raz drugi zaczął więc katechizować dzieci i opiekować się grupami duszpasterskimi w powiększającej się wspólnocie na Poczekajce.

Czas pobytu we wspólnocie lubelskiej był bardzo krótki, gdyż od 1977 roku o. Maurycy przebywał już w Rywałdzie Królewskim, gdzie był najpierw wikarym klasztoru. Dwa lata później w 1979 roku został mianowany gwardianem miejscowej wspólnoty i proboszczem parafii. Pełniąc te funkcje przez

\footnotetext{
${ }^{27}$ Por. Diploma licentiae, Archiwum KUL, sygnatura T 23340.

${ }^{28}$ Por. L. Kubrak, Pismo z dnia 11 X 1980 do kierownik dziekanatu Wydziału Teologicznego KUL, Archiwum KUL, sygnatura T 23340.

${ }^{29}$ Por. A.P. DYDYCZ, Życie poświęcone Bogu, s. 230.

${ }^{30}$ Por. P. DYDYCZ, Obediencja dla o. Maurycego Kubraka z dnia 13 VIII 1976 roku, Archiwum klasztoru w Lublinie II.
} 
sześć lat, dał się poznać jako niezmordowany krzewiciel kultu Matki Bożej Rywałdzkiej oraz gorliwy duszpasterz dbający o świętość swoich parafian. Opracował krótką książeczkę, gdzie zebrał dane historyczne i argumenty teologiczne uzasadniające kult maryjny w tym miejscu. Swoim współbraciom polecał troskę o to miejsce, które w jego opinii było szczególnie umiłowane przez Maryję.

W parafii powstała grupa oazowa oraz odrodziło się duszpasterstwo ministrantów. Nowy proboszcz przyczynił się do zintensyfikowania ruchu pielgrzymkowego i przeprowadził wiele prac remontowych w kościele i klasztorze. Bardzo dbał o zachowywanie ducha ubóstwa i nie dopuszczał do wyznaczania stawek za sprawowane posługi duszpasterskie. Przyjmował tylko dobrowolne ofiary składane przez ludzi. W ten sposób pozytywnie zmienił opinię wiernych o kapucynach w tym klasztorze, który był traktowany przez zakonników Prowincji Warszawskiej jako miejsce zesłania i stąd nie było chętnych do objęcia tej placówki.

O. Maurycy doprowadził do ufundowania w kościele klasztornym w Rywałdzie tablicy pamiątkowej ku czci Prymasa Stefana kard. Wyszyńskiego, który w 1956 roku przez kilka tygodni był więziony przez Urząd Bezpieczeństwa w klasztorze rywałdzkim. Została też zorganizowana izba pamięci niezwykłego więźnia oraz odnowiona cela, w której przetrzymywano Prymasa. Broniąc krzyży usuwanych ze szkół, o. Maurycy naraził się władzom partyjnym i był opisywany w miejscowych gazetach jako burzyciel ładu społecznego. Gdy podczas odpustu parafialnego we wrześniu 1984 roku, usiłując zakłócić uroczystości religijne, zorganizowano zabawę taneczną w pobliskiej miejscowości, proboszcz z Rywałdu udał się do tej wsi z krzyżem i wszedłszy na salę, wzywał ludzi do zaprzestania zabawy i udania się do kościoła ${ }^{31}$. Żyjąc w ubóstwie i kontemplacji, wzbudzał szacunek parafian i pielgrzymów, którzy nawiedzali sanktuarium.

\section{4. ŚWIADECTWO ŻYCIA I ZMAGANIA Z CHOROBĄ NA POCZEKAJCE}

Ostatnim miejscem ziemskiego pobytu ojca Maurycego był klasztor w Lublinie na Poczekajce, dokąd po raz trzeci przybył w 1985 roku. Pełnił w nim posługę duszpasterza w parafii, asystenta FZŚ i opiekuna jednej z grup Drogi Neokatechumenalnej. Jak zaznaczył w kwestionariuszu przesłanym do Kurii

${ }^{31}$ Por. A.P. DyDYCZ, Życie poświęcone Bogu, s. 232. 
prowincjalnej, sam wstąpił na drogę neokatechumenatu, podejmując formację słuchania Słowa Bożego i deklarując gotowość przechodzenia kolejnych etapów wtajemniczenia we wspólnocie ${ }^{32}$. W sierpniu 1987 roku zdiagnozowano u niego raka mózgu. Pierwszego sierpnia podczas Mszy świętej wieczornej tracił równowagę, opierał się o ołtarz i słaniał na nogach. Następnego dnia jego słowa były już niespójne i został zawieziony do kliniki okulistycznej, gdzie stwierdzono, że na prawym oku ma skrzydlik, to jest błonkę utrudniającą widzenie. Przeszedł operację i 12 sierpnia wrócił do klasztoru ${ }^{33} .18$ sierpnia trafił do szpitala PSK 4, gdzie stwierdzono raka mózgu, umiejscowionego w prawej komorze. Ze względu na postępująca chorobę, pismem Biskupa Lubelskiego z dnia 10 IX 1987 roku został zwolniony z obowiązków wikarego parafii ${ }^{34}$.

Janina Czerniej, opiekująca się nim podczas choroby, napisała w Kronice FZŚ: „Zawsze skromny, pogodny, uśmiechnięty i życzliwy, dla każdego znalazł czas (choćby to miało być kosztem własnego posiłku czy wypoczynku), każdemu śpieszył z pomocą. Chorował dwa i pół miesiąca i nie było ratunku. Zabrała go Matka Boża, której był czcicielem i miłośnikiem. Ojciec Maurycy odszedł w opinii świętości. Kto tylko miał szczęście spotkać go w swoim życiu, tak się o nim wyrażał" 35 . Ofiarował swoje życie Bogu przez wstawiennictwo Matki Bożej Rywałdzkiej. Swoje ostatnie imieniny obchodził 22 września 1987 roku, leżąc w łóżku, przy którym zgromadzili się bracia, składając mu życzenia. Kapucyni rozpoczęli nowennę do Honorata Koźmińskiego z prośbę o łaskę uzdrowienia ${ }^{36}$.

Postępująca choroba utrudniała o. Maurycemu pracę duszpasterską, ale zachował pełną świadomość i powierzał Bogu swoje cierpienie. Otoczony troską przez wspólnotę kapucynów i siostry ze wspólny Franciszkańskiego Zakonu Świeckich, znosił cierpliwie swoje dolegliwości i budował innych przykładem modlitwy oraz wyrzeczenia. W kronice wspólnoty franciszkanów świeckich na Poczekajce szeroko został opisany przebieg choroby ojca Maurycego. „Po krótkich i ciężkich cierpieniach odszedł od nas do Pana na zawsze ojciec Maurycy Ludwik Kubrak, prawdziwy syn duchowy św. Francisz-

32 Por. Ankieta, Archiwum klasztoru w Lublinie II.

33 Por. Kronika klasztoru i parafii OO. Kapucynów Al. Kraśnicka 76 od dnia 8.05.1988 do 28.07.1991, Archiwum klasztoru w Lublinie II, s. 72.

34 Por. B. PYlak, Pismo z dnia 10 IX 1987 roku, Archiwum klasztoru w Lublinie II.

${ }^{35}$ Kronika. Franciszkański Zakon Świeckich, Lublin „Poczekajka”, zapis pod datą 13.10.1987.

36 Por. Kronika klasztoru i parafii OO. Kapucynów Al. Kraśnicka 76 od dnia 8.05.1988 do 28.07.1991, Archiwum klasztoru w Lublinie II, s. 77. 
ka z Asyżu, wspaniały kapłan i zakonnik. Był naszym ukochanym, cenionym i szanowanym, wspaniałym asystentem duchowym. Był z nami krótko, bo zaledwie 20 miesięcy. W ciągu tego krótkiego czasu zapisał się na trwałe w naszych sercach. Zdążył poznać całą wspólnotę i poszczególnych jej członków. Dla każdego miał mądrą, dobrą radę dotyczącą problemów wspólnotowych bądź też rodzinnych czy osobistych. Miał dobre, czułe, kochające serce dla każdego. Mimo tak licznych obowiązków we wspólnocie zakonnej i parafii, miał czas dla FZŚ. Był wspaniałym, dyspozycyjnym asystentem i kierownikiem duchowym dla potrzebujących takiej pomocy"37.

$\mathrm{W}$ dniu 12 października przywieziono go z powrotem do klasztoru i położono w rozmównicy przy kancelarii, gdzie czuwała przy nim jego własna matka i rodzona siostra Danuta. Śmierć nastąpiła 13 października 1987 ro$\mathrm{ku}^{38}$. Uroczystościom pogrzebowym w kościele na Poczekajce przewodniczył bp Jan Śrutwa, biskup pomocniczy diecezji lubelskiej. Obecni liczni kapłani i świeccy mieli świadomość odejścia świątobliwego zakonnika. Jeden z braci kapucynów z Warszawy, obecny na pogrzebie, stwierdził, że ojciec Maurycy miał królewski pogrzeb. Bracia i siostry z III Zakonu modlili się o to, by „Bóg, jeśli taka Jego wola wyniósł go do chwały ołtarzy, by wszyscy poznali, że był dla nas wszystkich wzorem godnym do naśladowania, zarówno dla współbraci zakonnych, jak i świeckich" ${ }^{39}$. Grobowiec o. Maurycego na cmentarzu przy ul. Lipowej w Lublinie nadal nawiedza wiele osób przekonanych o jego świętości i proszących o jego wstawiennictwo u Boga. Halina Kosmala, która pielęgnowała go w czasie śmiertelnej choroby, pod jego wpływem wstąpiła do Franciszkańskiego Zakonu Świeckich i była przekonana, że świątobliwy kapucyn wypraszał jej potrzebne łaski. Ona sama wkrótce zachorowała i złożyła profesję na łożu śmierci.

\section{ISTOTNE WYMIARY DUCHOWOŚCI OJCA MAURYCEGO}

Cechami charakteryzującymi jego życie duchowe była modlitwa, pokuta, ubóstwo oraz szczere oddanie ludziom. Jego sposób medytacji i odprawiania Mszy świętej wskazywał na prawdziwe przeżywanie relacji z Bogiem i wzbudzał u innych szacunek dla jego głębokiej pobożności. Trwając w skupieniu na ado-

${ }^{37}$ Kronika. Franciszkański Zakon Świeckich, Lublin „Poczekajka”, zapis pod datą 13.10.1987.

${ }^{38}$ Por. Kronika klasztoru i parafii OO. Kapucynów Al. Kraśnicka 76 od dnia 8.05.1988 do 28.07.1991, Archiwum klasztoru w Lublinie II, s. 81-82.

${ }^{39}$ Kronika. Franciszkański Zakon Świeckich, Lublin „Poczekajka”, zapis pod datą 13.10.1987. 
racji Najświętszego Sakramentu medytował Mękę Pańską i zagłębiał się w rozważaniu tajemnic Różańca. Wierność codziennym ćwiczeniom i nabożność w ich spełnianiu sprawiała, że wierni prosili go o modlitwę wstawienniczą. Szczególnie ulubioną formą modlitwy była litania do Najświętszego Serca Jezusa. Obok pobożności maryjnej, kształtowanej w sposób szczególny w czasie pobytu w Rywałdzie Królewskim, o. Maurycy odznaczał się pietyzmem wobec o. Honorata Koźmińskiego, którego cnoty starał się naśladować.

Tym, co znamionowało o. Maurycego, był surowy tryb życia wyrażający się w licznych praktykach ascetycznych zarówno wynikających ze zwyczajów zakonnych, jak i tych, które sam sobie nakładał. Jadł bardzo mało i wybierał najgorsze kęski. Biczował się i spał na podłodze. Jego cela zakonna była wyposażona jedynie $\mathrm{w}$ nieliczne i proste meble. W zakresie ubóstwa był bardzo wymagający od siebie. Nie przyjmował zbędnych rzeczy i innym oddawał wszystko, co nie zgadzało się z duchem franciszkańskim. Częstym pytaniem, które sobie stawiał było to, jak na te rzeczy patrzyłby św. Franciszek z Asyżu. Niejednokrotnie zwracał uwagę na konieczność ubóstwa w wymiarze wspólnotowym, gdy bracia wyrażali potrzebę nowych zakupów do klasztoru.

Obowiązkowość i sumienność były cnotami wyróżniającymi jego podejście do życia. Ze względu na pokorę wymawiał się od przyjmowania gwardiaństwa, ale z posłuszeństwa uległ woli prowincjała i podjął posługę w Rywałdzie Królewskim. Taktowny i uprzejmy wobec braci, był wyrozumiały wobec słabości, ale stanowczy wobec zasad. Jego duchowy rozwój prowadził go do pokornego przyjmowania woli Bożej i uczenia innych zawierzenia Opatrzności. Dla innych stawał się przykładem wrażliwości na sprawy Boże i ludzkie.

W pełnieniu swych obowiązków duszpasterskich spalał się cały i wkładał w pracę całe serce. Jako katecheta, kapelan i proboszcz o. Maurycy promieniował miłością do Chrystusa i swoim przykładem prowadził do zawierzenia Maryi. Niejednokrotnie podejmował niekonwencjonalne sposoby działania, gdy w habicie szedł do restauracji w Wielki Piątek, albo w Wielkim Poście udawał się na dyskoteki, by zebranym tam katolikom przypominać o konieczności uszanowania okresów pokuty ${ }^{40}$. Oddany modlitwie i kontemplacji oraz podejmujący liczne posty, wyglądał surowo i ascetycznie, ale był uosobieniem łagodności i prostoty. Jego wygląd był swoistą prowokacją, gdyż widać było u tego człowieka głębokie przekonanie o świętości Boga i wzniosłym powołaniu człowieka, wolne jednak od jakiegokolwiek fanatyzmu. Jego kazania były

${ }^{40}$ Por. A.P. DYDYCZ, Życie poświęcone Bogu, s. 232. 
przygotowane i przemodlone. Poruszały one słuchaczy nie tyle pięknem słów i kaznodziejskim polotem, ale świadectwem życia, które emanowało z całej jego postawy.

W pamięci tych, którzy go spotykali, wywierał niezatarte wrażenie człowieka Bożego, który był cały oddany swej misji. Namaszczenie wypowiadanych przez niego słów nie miało nic z cukierkowatej pobożności, ale z surowością życia łączyło delikatność i wrażliwość na drugiego człowieka. Otwarty na nowe ruchy w Kościele, o. Maurycy trwał w wierności ideałom przyniesionym przez świętego Franciszka z Asyżu i ukazywał aktualność Ewangelii jako programu życia.

Ukazywanie ewangelicznych postaw ludzi, których papież Franciszek na-

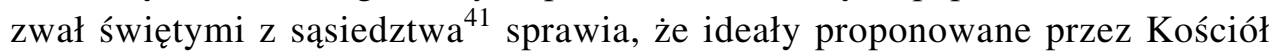
i formułowane $w$ ramach teologii moralnej staja się realne i ukazuja jako dostępne dla zwykłych ludzi. Każdy bowiem człowiek, otrzymując dar życia, zostaje wezwany do wielbienia swego Stwórcy i przynoszenia Mu chwały przez swoje dzieła. Ludzkie życie jest albo hymnem na cześć Boga, albo zawodzeniem ku czci wszystkich swoich słabości i upadków, które są wyrazem uległości bożkom tego świata. Postać Maurycego Kubraka, kapucyna z lubelskiej Poczekajki, doskonale ilustruje zmaganie człowieka o osiągnięcie ideału doskonałości ewangelicznej na drodze powołania zakonnego.

\section{BIBLIOGRAFIA}

Ankieta, Archiwum klasztoru w Lublinie II.

BARTOSZEwSKI G., Świętość niekanonizowana Warszawskiej Prowincji Braci Mniejszych Kapucynów, w: W służbie pokoju i dobra. Jubileusz pięćdziesięciolecia odrodzenia Warszawskiej Prowincji Kapucynów. Księga pamiątkowa, red. R. Prejs, Bracia Mniejsi Kapucyni, Warszawa 2002, s. 391-399.

41 „Lubię dostrzegać świętość w cierpliwym ludzie Bożym: w rodzicach, którzy z wielką miłością pomagają dorastać swoim dzieciom, w mężczyznach i kobietach pracujących, by zarobić na chleb, w osobach chorych, w starszych zakonnicach, które nadal się uśmiechają. W tej wytrwałości, aby iść naprzód, dzień po dniu, widzę świętość Kościoła walczącego. Jest to często «świętość z sąsiedztwa», świętość osób, które żyją blisko nas i są odblaskiem obecności Boga, albo, by użyć innego wyrażenia, są «klasą średnią świętości»”. FRANCISZEK, Adhortacja apostolska Gaudete et exultate, Watykan 2018, nr 7. 
Bartoszewski G., Zaświadczenie, Archiwum KUL, sygnatura T 23340.

CYGAN J.M., Maurycy Kubrak, kapucyn, we wspomnieniach mieszkańców Białej Podlaskiej, „Podlaski Kwartalnik Kulturalny” 1995, nr 1, s. 29-41.

DerdzIUK A., Świadkowie miłości Boga i człowieka, w: Fructus Spiritus est Caritas. Księga jubileuszowa ofiarowana ks. profesorowi Franciszkowi Drączkowskiemu, red. M. Wysocki, Wydawnictwo KUL, Lublin 2011, s. 587-590.

Diploma licentiae, Archiwum KUL, sygnatura T 23340.

DYDYCZ A.P., Życie poświęcone Bogu, w: TENŻE, Niosąc ziarno na zasiew, Fundacja Jana Pawła II, Rzym-Lublin 1992, s. 219-234.

DYDYCZ P., Obediencja dla o. Maurycego Kubraka z dnia 13 VIII 1976 roku, Archiwum klasztoru w Lublinie II.

Dzieje klasztoru lubelskiego OO. Kapucynów w drugim 1000-leciu chrześcijaństwa w Polsce, Kronika klasztorna, Archiwum klasztoru w Lublinie I.

FRANCISZEK, Adhortacja apostolska Gaudete et exultate, Watykan 2018.

KASPRZYK L., Pozwolenie ministerstwa nauki, szkolnictwa i techniki, z dnia 19 lutego 1973 roku, Archiwum KUL, sygnatura T 23340.

Kronika klasztoru i parafii OO. Kapucynów Al. Kraśnicka 76 od dnia 8.05.1988 do 28.07.1991, Archiwum klasztoru w Lublinie II.

Kronika parafii Niepokalanego Serca Maryi, Lublin Konstantynów, Archiwum klasztoru w Lublinie II.

Kronika. Franciszkański Zakon Świeckich, Lublin „Poczekajka”, Archiwum FZŚ Lublin II.

KubraK L., Pismo do Dziekana z dnia 13 stycznia 1976 roku, Archiwum KUL, sygnatura T 23340.

KubraK L., Pismo z dnia 11 X 1980 do kierownik dziekanatu Wydziału Teologicznego KUL, Archiwum KUL, sygnatura T 23340.

Kubrak L., Podanie do Księdza Dziekana Wydziału Teologicznego KUL, Archiwum KUL, sygnatura T 23340.

Kubrak L., Podanie do Rady Wydziału Teologicznego KUL, Archiwum KUL, sygnatura T 23340.

KUbRaK L., Podanie o przyjęcie na studia na KUL, 28 IX 1972, Archiwum KUL, sygnatura T 23340.

Protokół komisji egzaminu magisterskiego, Archiwum KUL, sygnatura T 23340.

PYlaK B., Pismo z dnia 10 IX 1987 roku, Archiwum klasztoru w Lublinie II.

SZYMAŃSKI A., Cicha działalność kapelańska o. Maurycego Kubraka, w: TENŻE, Kapucyni kapelani szpitalni i więzienni po drugiej wojnie światowej w Lublinie, mps, Biblioteka WSD Kapucynów w Lublinie, Lublin 1983, s. 15-16.

\author{
REALIZACJA POWOŁANIA ZAKONNEGO \\ MAURYCEGO LUDWIKA KUBRAKA OFMCap (1937-1987)
}

\title{
STRESZCZENIE
}

Kapucyn Maurycy Ludwik Kubrak (1937-1987) został zapamiętany jako charyzmatyczny duszpasterz, który oddziaływał na wiernych swoją pokorą, prostotą oraz duchem pobożności i ubóstwa. Pracując w Białej Podlaskiej i Lublinie, jako nauczyciel religii, był nazywany kate- 
chetą z magnesem. W swojej posłudze jako kapelan szpitalny w Lublinie oraz duszpasterz sióstr w Nowym Mieście nad Pilicą odznaczał się wiernością obowiązkom i ofiarną dyspozycyjnością nie szczędzącą siebie. Jako proboszcz w Rywałdzie Królewskim szerzył kult maryjny i rozwijał duszpasterstwo w sanktuarium. Jego cierpliwość i umiłowanie krzyża ujawniło się podczas śmiertelnej choroby, którą przeżywał z wyjątkowym poddaniem się woli Bożej. Zmarł w opinii świętości.

Słowa kluczowe: Kapucyni; Maurycy Kubrak; świętość; duszpasterstwo. 